\title{
Promoting communication skills for information systems students in Australian and Portuguese higher education: Action research study ${ }^{1}$
}

\author{
Pedro Isaias ${ }^{*} \&$ Tomayess Issa** \\ * Universidade Aberta (Portuguese Open University), Lisbon, Portugal \\ *** Curtin University, Perth, Australia
}

\begin{abstract}
This paper aims to examine the value of communication skills learning process through various assessments in Information Systems (IS) postgraduate units in Australia and Portugal. Currently, communication skills are indispensable to students in expanding their social networks and their knowledge at university and in the future workplace, since businesses expect their employees to have strong communication and presentation skills. This paper provides empirical evidence based on the anonymous quantitative and qualitative data collected during two years from 126 postgraduate students, which were collected via formal and informal feedback. Various assessment methods were used in Information Systems units to promote and develop the communication skills; these assessments are: reflective journal, business plan and prototype, discussion forum, presentation, and final examination. A Communication skills model (CSM) was developed based on Action research principles to promote the assessments which will assist IS students to enhance their communication skills. The research outcomes indicated that integrating communication skills in the assessments will allow students to promote their communication skills and boost their self-esteem skills. Furthermore, this paper added a new theoretical and practical contribution to higher-education teaching and learning literature, especially the action research for teachers to promote and develop communication skills among students. Finally, integrating these skills in the units should meet the objectives and aims of the units, Master's degrees, universities, and businesses' needs, and satisfy our student's needs.
\end{abstract}

Keywords: Action Research and Communications skills, Information Systems Units, Higher Education

\section{INTRODUCTION}

In the twenty-first century, there have been various changes in the economic, social, technological, marketing and management fundamentals in respect of the communication skills, which are required by workers to complete their job in a proficient way. This shift allows businesses and companies nationally and internationally to explore with enthusiasm the prerequisites for outstanding communication skills, i.e. writing, reading, critical thinking and presentation, among information systems graduates. This shift is required especially in the delivery, curriculum and pedagogy of higher education. These skills should be integrated throughout the curriculum for both undergraduates and postgraduates. Integrating and mixing these skills in the unit will promote and enhance students' personalities and increase their confidence in approaching their studies and workplace in the future. Several studies (Yang et al. 2008; Worley 2008 ; Pavolvich et al. 2009; Li 2010 ; Kuzma 2011; Van Deursen et al. 2011) indicate that integrating these skills in various assessments (i.e. reflective journal, business plan and prototype, discussion forum, presentation, and final examination) will make them more challenging, exciting, and interactive, and encourage students to complete them before or on time.

This study will present an Australian and Portuguese perspective in developing assessments that based on CSM model principles to promote and develop the essential communication skills, especially among IS Students in a higher-education sector. This study aims to examine students' reactions to the assessments which were adopted in these units to enable them to acquire and assimilate these skills, through informal and formal feedback from

\footnotetext{
1 This is the final draft of the published paper Isaias, Pedro and Issa, Tomayess. 2013. Promoting Communication Skills for Information Systems Students in Australian and Portuguese Higher Education: Action Research Study. Education and Information Technologies 18 (April 2013). Final version available at http://link.springer.com/article/10.1007\%2Fs10639-013-9257-9
} 
the following units: Information Systems (IS6) (face-to-face mode), Applied Project (AP) (distance learning online mode) and Models and Technologies for e-Business (MTeB) (face-to-face mode) in Australia and Portugal.

The outcomes from this study will endorse universities' graduate attributes, business needs and assist the students to acquire the communication skills, which are necessary in the rest of their studies and for their future workplace and will add a valuable significance from theoretical and practical contribution to higher-education teaching and learning literature, especially the action research for teachers. This study is organized as follows: action research, Assessments and Communication skills, research methods and questions, participants, results, discussion and theoretical and practical significance, and conclusion.

\section{ACTION RESEARCH}

Action research becomes very popular in the teaching and learning sector to generate a solution to practical problems and allow the researchers to engage in the research and subsequent to develop and implement activities in their units. Mertler (2006, p.2) posits that action research is defined as any

"Systematic inquiry conducted by teachers, administrators, counsellors, or others with a vested interest in the teaching and learning process or environment for gathering information about how their particular schools, operate, how they teach, and how their students learn."

To carry out this process especially in the teaching and learning sector, a strategy should integrate participation, collaboration and experience among teachers/researchers and students. By the same token, Reason \& Bradbury (2001, p.1) posits that action research is a

"Participatory, democratic process concerned with developing practical knowing in the pursuit of worthwhile human purposes."

Action research aims to connect theory to practice and to apply several approaches and assessments to improve the educational practice and students' professional skills. Mills (2000) perceive that teachers/researchers who involve in action research and taking their students' perspective in their teaching will have the opportunity to develop and enhance students' knowledge and their communication skills as well. Furthermore, using students' informal and formal will assist teachers/researchers to improve the assessments and ensure students' skills and knowledge, especially the communication skills, which are required, not only in the university but the workforce level as well will improve.

In this study, the researchers adapted the principles of research actions' models (Elliot 1991; Avison et al. 1999; Mills 2007; Sagor 2011; McNiff and Whitehead 2005; McGrath and O'Toole 2012) in line to develop the Communication skills model (CSM) to promote and improve IS students communication skills in Australia and Portugal (see Figure 1).

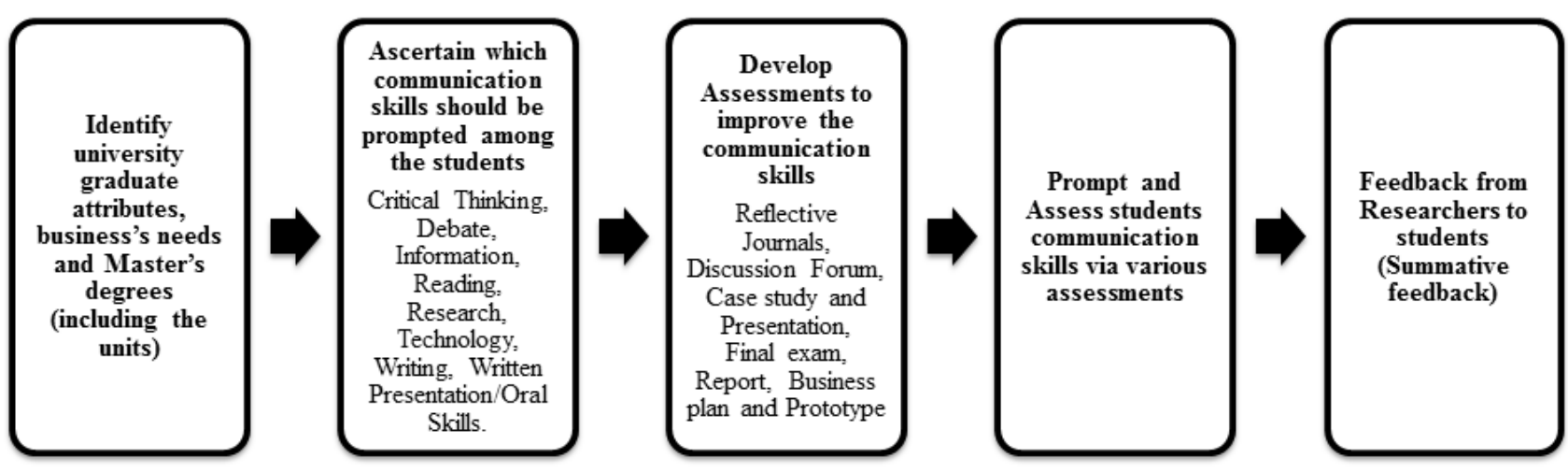

Fig 1: Communication skills model (CSM) for IS6, AP and MeTB Postgraduate Units in Australia and Portugal Prepared by the researchers

The communication skills model (CSM) is divided into five stages, and each stage is containing information for the subsequent stage. Firstly, the researchers identify university graduate attributes, business's needs as well the 
Master's degrees (including the units). Secondly, based on these findings the researchers ascertain which communication skills should be promoted among the students, and subsequently, the assessments are developed. Thirdly, the researchers assess students' communication skills via the assessments. Lastly, the researchers provide feedback to confirm if communication skills are promoted. The CSM is an on-going process until students communication skills are promoted and improved among the Information Systems Students in Australia and Portugal.

\section{ASSESSMENTS AND COMMUNICATION SKILLS}

Currently, communication skills are essential in the study and in the workplace, as via these skills students can develop their personality, self-esteem, self-confidence and self-possession. (Tanian and Ryan 1998; Drury and Taylor 1999; Pavolvich et al. 2009). Postgraduate information systems students will have the ability to think critically since assessments (i.e. reflective journal, business plan and prototype, discussion forum, presentation, and final examination), will equip students with the necessary skills to analyse and solve problems that will be encountered in real life (Woei and White 2010). According to the literature review (Albitz 2007; Biesta and Stams 2001; Halpern 1998; Hattangdi and Ghosh 2008; Tucker et al. 1998; Wolcott et al. 2002 ) there is a call from businesses to academics to integrate communication skills in their units as these skills are becoming important and essential not only in the education sector but also in business.

For this study, the researchers developed specific assessments (i.e. reflective journal, business plan and prototype, discussion forum, presentation, and final examination), targeting communication skills in IS6, AP and MTeB units. Each researcher developed a set of assessments for her/his unit to match the objectives and aims of the units, Master's degrees and universities. The main objective of these assessments is to prepare the students for real life and business and to allow them to join the Information Systems profession easily in the future.

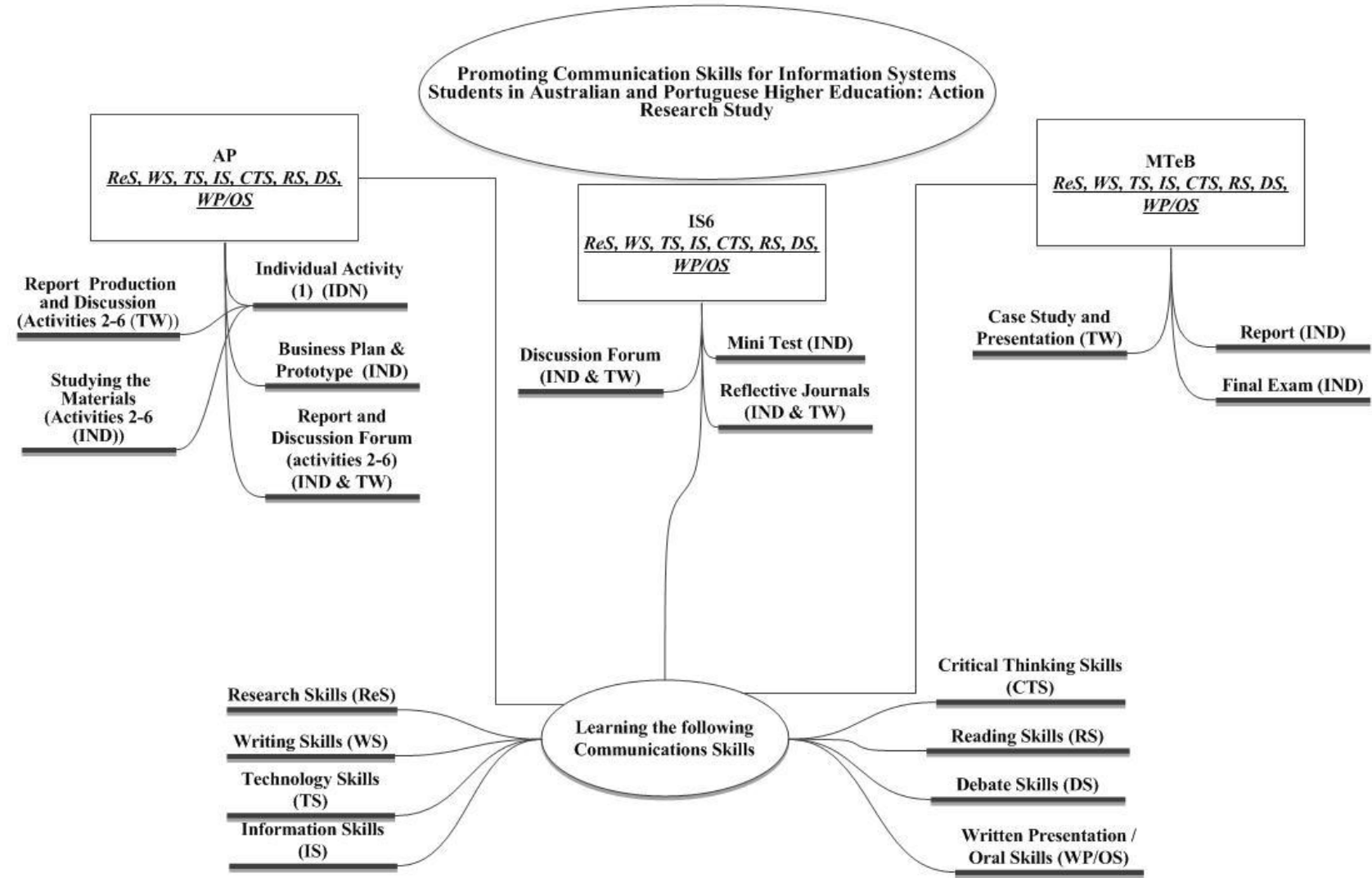

IND: Individual ; TW: Team Work Prepared by the Researchers

Fig 2: Assessments in the IS6, AP and MeTB Postgraduate Units in Australia and Portugal Prepared by the researchers 
Figure 2 illustrated the assessments in IS6, AP and MeTB postgraduate units in Australia and Portugal; as well, the communications skills will be obtained after completing the assessments. Under this section, the researchers will identify the assessments in each unit and provide a breakdown of the marks allocated to each of these assessments as shown in table 1.

\begin{tabular}{|c|c|c|c|c|c|c|c|c|}
\hline No. & $\begin{array}{c}\text { Assessment } \\
\text { Activity IS6 }\end{array}$ & $\%$ & $\begin{array}{c}\text { Assessment Activity } \\
\text { Applied Project } \\
\text { (AP) }\end{array}$ & $\%$ & $\begin{array}{c}\text { Assessment Activity } \\
\text { Model and Technologies } \\
\text { for e-Business 2009 } \\
\text { (MTeB) }\end{array}$ & $\%$ & $\begin{array}{c}\text { Assessment Activity } \\
\text { Model and Technologies } \\
\text { for e-Business 2010 } \\
\text { (MTeB) }\end{array}$ & $\begin{array}{c}\% \\
2\end{array}$ \\
\hline $\begin{array}{c}\text { Mini Tests } \\
\text { Mini Test } \\
\text { Mini Test }\end{array}$ & $25 \%$ & $\begin{array}{c}\text { 1 Individual Activity } \\
\text { (participation in } \\
\text { Forum) }\end{array}$ & $10 \%$ & $\begin{array}{c}2 \text { case studies (Team } \\
\text { work) }\end{array}$ & $30 \%$ & 1 case study (Team work) & $20 \%$ \\
\hline 2 & $\begin{array}{c}\text { Reflective Journal } \\
\text { (7 Individual and 3 } \\
\text { Teamwork) }\end{array}$ & $40 \%$ & $\begin{array}{c}5 \text { Group Activities } \\
\text { (10\% for each } \\
\text { activity) }\end{array}$ & $50 \%$ & Report (Individual work) & $30 \%$ & Report (Individual work) & $50 \%$ \\
\hline 3 & $\begin{array}{c}\text { Contribution to } \\
\text { Group Discussions } \\
\text { - Blackboard }\end{array}$ & $10 \%$ & Final Work & $40 \%$ & Final Exam & $40 \%$ & Final Exam & $30 \%$ \\
\hline & Total & $100 \%$ & Total & $100 \%$ & Total & $100 \%$ & & Total \\
\hline
\end{tabular}

Table 1: Assessments in IS6, AP and MTeB - Australia and Portugal

\section{IS6 ASSESSMENTS}

IS6 is considered an essential unit for the Master's degree students at the Australian University in Australia, especially for understanding the relationship between computers and users, usability and Human Computer Interaction, and enhancing the functionality and performance of interfaces and websites. The students' informal and formal feedback, noted that the IS6 unit is challenging, fun and informative, as the majority of the students were very positive about the structure and teaching style. IS6 materials and assessments are in the English language. Under IS6 unit, the researcher assigned three assessments comprising reflective journals, mini-tests and discussion board; these assignments are mainly individual, although in the reflective journals assessment some of the work can be achieved as a group to develop teamwork skills. The assessments for the IS6 unit were designed with university graduate attributes in mind (Curtin University 2010, n.d.). The IS6 assessments are targeting the following communication skills: Research, writing, technology, information, critical thinking, reading, debate and written presentation and oral skills (see Figure 2).

The first mini-test was composed of questions that will enhance the middle-and high-level thinking of students, as 15 multiple-choice short-answer questions based on the lecturers' notes were mainly aimed at students' middle-level thinking. The case study was mainly aimed at the students' high-level thinking, as they were required to identify the website's problems and adjust it according to the principles and guidelines of HCI. The second mini-test was an open book exam moving away from memorization into the application; this too targeted students' high-level thinking. The second mini-test was composed of four questions based on students' understanding of the articles at hand, in which they presented their perspective as a report. This assessment is targeting the following communication skills: research, writing, technology, information, critical thinking and reading skills.

The second assessment was the reflective journal assessment, which was designed to provide students with experience in critically, creatively and reflectively reviewing and recording the main key points from and their thoughts about material from textbooks, journal articles, and the Internet. Furthermore, to promote teamwork skills among students, some journals were completed as a group project, and later each group member will present his/her part to their colleagues as an oral presentation. This assessment is targeting the following communication skills: research, writing, technology, information, critical thinking, reading, debate and written presentation and oral skills.

The third assessment was the contribution to group discussions - blackboard. Students were expected to contribute actively to the group discussion under the blackboard. Contributions were based on their understanding of the material provided and they sought. The mark allocated not only took into account the quantity of contributions but also more importantly considered the quality of the contributions by each of those students. This assessment is targeting: research, writing, technology, information, critical thinking, reading and 
debate. Furthermore, a group discussion was used to promote students teamwork, as some activities was completed via this tool.

\section{AP ASSESSMENTS}

AP is considered a key unit for the Master's degree students from the Universidade Aberta (Portuguese Open University). AP is mainly focused on learning concepts and related tools in ERP, CRM, Portal, and Balanced Scorecards, developing e-commerce websites, and producing a business plan for an e-commerce initiative. This unit is similar to a capstone unit as it wraps up several technologies learnt previously in the master degree but more focused in this unit. The prototype is a key aspect of practising the technologies and in some cases also serves as a starting point for the students' dissertations. It is on-line nature makes this unit very demanding for students, who need to fulfil a set of activities and goals to complete it with success. For the same reasons, students appreciate the unit very much, reporting it as being very practical and helping them in their future lives. Under AP unit, the researcher assigned a mix of individual activities (studying the materials, preparing a business plan and prototype, discussion of the reports and discussion in an online forum) with group activities (production and discussion of a report). The AP assessments are targeting the following communication skills: Research, writing, technology, information, critical thinking, reading, debate and written presentation and oral skills (see Figure 2).

The first assessment, individual activity assessment which rated their participation in a forum based on a specific task. This task involved study materials, journal papers and other materials that must be studied by students first, after which each of them was required to participate in a forum via Moodle. The lecturer was the facilitator, guiding the discussions and the student participation. Individual participation was rated according to the quality and relevance of the posting. Interaction and response to other students was also considered and rated. This assessment targeted students' following communication skills: research, writing, information, critical thinking, debate and reading skills.

The second assessment was the group activities. This assessment was the most attractive activity to the students, since the lecturer sets up five activities, and for each activity, students were provided with materials relating to the contents of the specific activity. Then the lecturer assigned a task (e.g. Analysis of a specific piece of software) and students prepared a report as a group and presented (and defended it) on-line via the Moodle Forum. In short, each activity consisted of: (1) reading the texts and studying the materials; preparing the analysis of the software and writing a report as a team; and (3) on-line presentation and defence of the report. The unit each activity was worth $10 \%$ - there were five group activities plus one individual activity (participation in the forum - worth 60\%). This assessment is targeting the following communication skills: research, writing, technology, information, critical thinking, reading, debate and written presentation skills.

Finally, an individual work task was assigned to each student worth $40 \%$ of the total grade. This assessment is targeting the following communication skills: research, writing, technology, information, critical thinking, reading, and written presentation skills.

\section{MTEB ASSESSMENTS}

MTeB is a unique unit in ISEG - Technical University of Lisbon, as it is considered a part of two Master's degrees and is mainly focused on e-Business. MTeB is also focused on learning concepts and related tools in ERP, CRM, Portal, and Balanced Scorecards (similar to AP), analysing real case studies that give students the opportunity to learn the skills which are required for the workplace, and preparing them for real life in the future. Student comments were very positive and enthusiastic, and it was concluded that this unit is becoming more appealing and attractive to students who wish to complete their dissertations on the same unit themes in the future. This is valid for the two different Master's degrees where the unit is taught. MTeB and AP are run in the Portuguese language. Under MTeB unit, the researcher assigned a mix of individual activities (report writing and final examination) with group activities (case study analysis and presentation). The MTeB assessments are targeting the following skills: Research, writing, technology, information, critical thinking, reading, debate and written presentation and oral skills.

The first assessment is case study (two in 2010, and one in 2009). This assessment consisted of reading a case study and later working as a team to prepare an analysis and presentation of the case study in the class. Several guidelines were given to the students on how to analyse a case study, and how to report and discuss it. This 
assessment targeted students' following communication skills: research, writing, information, critical thinking, debate and reading skills. This assessment is targeting the following communication skills: writing, information, critical thinking, reading, debate and written presentation and oral skills.

The second assessment is a report. This assessment was an individual assessment and consisted of being assigned a topic in e-Business in order to develop a literature review about it, and produce a study with a research method in relation to the topic. Via this method, several papers were produced on specific topics. Finally, the students had to present their reports to the class on the last day of the semester. This assessment targeted students' following communication skills: research, writing, information, critical thinking, debate and written presentation and oral skills.

A final exam was also given to the students to assess their understanding of the unit contents. This final assessment targeted students' following communication skills: reading, writing, information, and critical thinking.

\section{COMMUNICATION SKILLS}

Communication skills are essential and important for IS students, since these students are focusing on the computer to develop programs and design and configure devices, plan, and develop methodologies and systems; therefore, to shift students' mind-sets, the researchers designed specific assessments (i.e.: reflective journal, business plan and prototype, discussion forum, presentation, and final examination) to present students with the experience of critically, creatively and reflectively reviewing and discussing the most important aspects and concepts with their colleagues. Presenting this type of assessments to IS postgraduate students will entail two benefits: first, the students will need to analyse and synthesize the diverse types of academic publications for the assessments; second, these assessments will raise communication skills in research, writing, technology, information, thinking, reading, debate and written/oral presentation (see Figure 2). Consequently, these units ultimately will change the information systems students' mind-sets and prepare them to have the necessary knowledge and skills which are required by the workplace in the future.

In this respect, numerous studies (Wingate 2010; Hubner et al. 2010; Li 2010 ; Wallace et al. 2004; Worley 2008 ) have indicated that writing and reading skills are significant in the business sector, as students should have all the basic knowledge behind writing, reading, reflecting, and very high-level thinking, and this can be achieved by practice and interaction during class time or through the discussion board and forums via the blackboard and Moodle FLECS facility (Tucker et al. 1998). These skills - research, writing, technology, information, critical thinking, reading, debate and presentation - can be developed by using assessments such as reflective journals and report writing. These assessments required students first to locate the articles, which were required to complete the assessments, and later upload the article details to the Endnote software for citations and bibliography.

Using this routine (daily/weekly) will encourage students to promote their searching, researching and technology skills, including the use of the Endnote software to organize their reference list (Wallace et al. 2004). To emphasize the importance of these skills, the researchers arranged with the university librarian to present a session on how to locate these articles, how to use the Endnote software and how to present and prepare a business report; the majority of the students confirmed that this exercise was outstanding and helpful, as this information was useful both for these units and for others. Later, after promoting the skills mentioned above, the researchers sought to promote the critical thinking skills. According to Woei and White (2010, p.4277),

"The ability to think critically is viewed as an important aspect of learning because it equips students with the ability to analyze and solve problems which they might meet in real life."

This skill can be promoted by asking students to read several academic journals, papers and articles and using a specific template to teach students how to criticize these journals and add their perspective.

The communication skills centre at the Australian University developed the analysis and evaluation of a reflective journal template and it contains the following questions. (1) Reading (full citation required, including author, title, date, publication details, and page numbers). What is the subject/theme of this article, (3) Argument/Findings (What is the author's argument?), (4) Evidence (How do this author's views compare with what others have said on the same or a similar topic?), (5) Observations (What are your own thoughts on the subject?), and (6) Conclusion. 
This exercise confirmed that the majority of communication skills were acquired via using reflective journals and assessment reports, and these skills can be achieved by weekly practical exercises. To confirm whether the students were developing these skills, the researchers provided weekly formative feedback, during class time, via the discussion board FLECS facility, or via email, to tackle any problems immediately in order to improve the second submission. The majority of the students stated that completing this assessment promoted and developed their reading, writing, and critical thinking skills, which are important in their current studies at the university and in the workplace in the future.

Furthermore, teaching communication skills is unlimited to the above. The most vital skill is that of oral presentation, which is considered an important skill, as students will present their ideas, thoughts and perspective on the topic, and later a debate will be raised between students and lecturers to clarify some issues behind it. This exercise will increase their confidence and develop their self-esteem (Li 2010 ; Kuzma 2011). Teaching does not only take place face to face; on the contrary, technology is playing a major role in teaching, including higher education. Various studies (Hubbs and Brand 2010; Hubner et al. 2010; Chi et al. 2011; Scott 2011) indicate that integrating technology in teaching will make the classes more attractive and appealing to students, as this blending teaching method will allow students to learn from each other and share their knowledge and experience via various tools: e.g. a discussion board under the blackboard.

Finally, preparing these assessments was challenging for the researchers, as each assessment targeted specific skills in the units; also, the researchers developed and designed these assessments to match unit, degree, university and business needs, and of course to satisfy our students' desires. Therefore, the researchers developed these assessments on the basis of the literature review and student feedback to: 1) expand their students' knowledge and skills, and 2) increase the students' motivation, inspiration and enthusiasm toward the units.

\section{METHODOLOGY AND RESEARCH QUESTION}

For this study, the researchers used qualitative and quantitative approaches, to examine whether the assessments in IS6, AP and MTeB will promote students' communication skills; this is the study's research question. It is necessary to combine these approaches for this study to capture the immense range of perspectives and information from the students regarding the promotion of communication skills (Creswell 2003; Gilbert 2006; Hesse-Biber 2010). Several studies indicated that using both approaches will reduce the gaps in the findings, make the outcomes more interesting, and, most importantly, reduce the errors in the findings (Gilbert 2006; Harrison and Reilly 2011; Maudsley 2011). For this study a qualitative approach is essential as this approach enables researchers to recognize students' attitudes, behaviours, motivations, and concerns regarding the unit, teaching, assessments, workload and any improvements should be carried out by the researchers for the future (Creswell 2003; Karkukly 2011; Teddlie and Tashakkori 2009). A quantitative approach is also crucial, as researchers collected some statistical data via students feedback the formal and informal methods to examine the unit, teaching, assessments and workload (Karkukly 2011; Sullivan 2011; Westerman 2011; Westerman and Yanchar 2011). For this study, the data will be presented in the quantitative and qualitative approaches.

For the IS6 unit, students' feedback was collected over two periods in the semester. In the first, informal feedback was collected while students were still undertaking the unit. This feedback is a teaching and learning initiative in which during the semester students are asked to provide anonymous feedback on the unit. Students are usually given the chance to provide comments on what they want the lecturer to continue, to stop and to start doing, thus providing an opportunity for both students and lecturers to benefit from the course, by enhancing the methods of teaching and learning. In the second period, feedback was collected at the end of the semester through the University's formal feedback system 'eVALUate'.

For the AP and MTeB units, students were asked to provide anonymous feedback at the end of the semester in relation to the unit, the teaching and the materials used. Online forums were used for the AP unit, while paper forms were used for the MTeB unit. Both instruments used a Likert scale ranging from one to five.

In this study, the researchers will examine and investigate if the assessments in IS6, AP and MTeB will promote and enhance students' communication skills in their university studies and in the lifelong learning process. As was indicated previously, researchers are using the formal and informal feedback on the unit and the teaching to conduct this study.

\section{PARTICIPANTS}


For this study, the participants are 126 from IS6, AP, and MTeB units from Australia and Portugal, which focus mainly on design from the information systems perspective. Table 2 provides a breakdown of the participants in each unit.

\begin{tabular}{|c|c|c|c|c|c|}
\hline \multirow{3}{*}{ 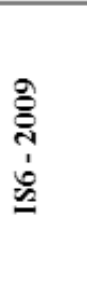 } & Qualification & \# & Gender & Nationality & Work Experience \\
\hline & Master of Commerce (IS) & 9 & $\begin{array}{l}3 \text { Female } \\
6 \text { Male }\end{array}$ & $\begin{array}{l}6 \text { Asia, } 2 \text { Mauritius, } 1 \\
\text { India }\end{array}$ & 5 Middle, 4 Low \\
\hline & Master of Information Systems & 11 & $\begin{array}{l}3 \text { Female } \\
8 \text { Male }\end{array}$ & $\begin{array}{l}5 \text { Asia, } 1 \text { Middle East, } 2 \\
\text { Africa, } 1 \text { India, } 1 \text { Iran, } 1 \\
\text { USA }\end{array}$ & 2 Middle,9 Low \\
\hline \multirow{2}{*}{ 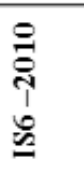 } & Master of Commerce (IS) & 7 & $\begin{array}{l}3 \text { Female } \\
4 \text { Male }\end{array}$ & $\begin{array}{c}1 \text { Africa, } 2 \text { Asia, } 1 \text { Iran, } 1 \\
\text { Australia, } 2 \text { India }\end{array}$ & $\begin{array}{c}3 \text { High, } 2 \text { Middle, } 2 \\
\text { Low }\end{array}$ \\
\hline & Master of Information Systems & 8 & $\begin{array}{l}2 \text { Female } \\
6 \text { Male }\end{array}$ & $\begin{array}{c}1 \text { Africa, } 2 \text { Fiji, } 1 \text { Asia, } 1 \\
\text { India, } 3 \text { Middle East }\end{array}$ & 4 Low, 4 Middle \\
\hline$\dot{\hat{\sigma}}$ & $\begin{array}{c}\text { Master of E-Commerce and } \\
\text { Internet }\end{array}$ & 7 & 7 Female & 7 Portugal & 5 High, 2 Middle \\
\hline$\dot{\xi}$ & $\begin{array}{c}\text { Master of E-Commerce and } \\
\text { Internet }\end{array}$ & 17 & 5 Female & 3 Africa, 14 Portugal & $\begin{array}{c}11 \text { High, } 3 \text { Middle, } 3 \\
\text { Low }\end{array}$ \\
\hline$\stackrel{m}{\frac{m}{2}}$ & Master in Corporate Sciences & 18 & $\begin{array}{l}5 \text { Female } \\
13 \text { Male }\end{array}$ & $\begin{array}{c}1 \text { Africa, } 1 \text { Austria, } 16 \\
\text { Portugal }\end{array}$ & $\begin{array}{l}0 \text { High, } 2 \text { Middle, } 16 \\
\text { Low }\end{array}$ \\
\hline 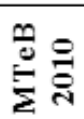 & Master in Corporate Sciences & 31 & $\begin{array}{l}11 \text { Female } \\
20 \text { Male }\end{array}$ & 31 Portugal & $\begin{array}{c}1 \text { High, } 4 \text { Middle, } 26 \\
\text { Low }\end{array}$ \\
\hline$\stackrel{m}{\varrho}$ & $\begin{array}{l}\text { Master in Management of } \\
\text { Information Systems }\end{array}$ & 18 & $\begin{array}{l}7 \text { Female } \\
11 \text { Male }\end{array}$ & 2 Africa, 16 Portugal & $\begin{array}{c}11 \text { High, } 5 \text { Middle, } 2 \\
\text { Low }\end{array}$ \\
\hline
\end{tabular}

Table 2: Participants - IS6, AP and MTeB - 2009 - 2010

The IS6 participants are a mixture of students from the Master of Information Systems and the Master of Commerce (Information Systems) courses; for the former it is considered a core unit, while for the latter it is optional. The students are from different nationalities (i.e. Australia, Asia, Mauritius, India, Middle East, Africa, Iran, USA, and Fiji) with various work experience. Work experience plays a major role in the class, as students with solid experience share their knowledge and real-life experience. This type of interaction encourages more collaboration and cooperation between students and makes the class more enjoyable.

The AP participants are 100 percent Portuguese in 2009, although there were some students from Africa in 2010. Most of them have a lot of work experience, which is excellent in terms of the practical contributions and real applied knowledge that they bring from their lives to their on-line participation and interaction.

The majority of the students in MTeB unit are Portuguese. The students from the Master of Corporate Sciences had little work experience, whilst the students from the Master of Management of Information Systems were highly experienced professionals with much work experience. From the researcher's perspective, it was interesting to note that students with less experience were full-time students while students with excellent working experience were part-time students.

The diversity of IS6, AP and MTeB participants presents a huge challenge to the researchers, especially in designing the assessments, as students' qualifications, nationality and work experience should be considered in order to make the assessments more challenging and exciting. Furthermore, the assessments should be designed and structured well to encourage students to develop the necessary communication skills that are required in the lifelong learning process. 


\section{RESULTS - STUDENTS REFLECTIONS AND FEEDBACK}

This study aims to examine students' reactions toward the assessments of IS6, AP and MTeB units, and is designed to investigate and assess whether completing these assessments (i.e.: reflective journal, business plan and prototype, discussion forum, presentation, and final examination) enables students to enhance their communication skills or gain new ones.

The IS6 unit has various assessments that assist students to develop some or maybe all of the communication skills. For example, the reflective journal assessment is considered a way to assist students to learn how to write in a professional way similar to that of articles in academic journals. Several authors posited (Clarke 2003; Hubbs and Brand 2010; Hubner et al. 2010) that the reflective journal assessment is an excellent and important tool in higher education sector, as through it students will develop and enhance their communication skills. The reflective journal idea was developed by Dewey (1933), who confirmed that this tool will assist students not only to develop their communication skills but also in problem solving, critical thinking, writing and reading.

At the beginning of the semester, the IS6 lecturer shared a template for analysing and evaluating a journal article, which was designed by the Communication skills centre at the university. At the beginning, it was a challenging exercise for students to summarize two articles according to the template and to write only one thousand words. The lecturer's formative feedback plays a crucial role in this situation, as students learn from their mistakes, and regular feedback prevents students from repeating the same mistakes and improves their learning behaviour and thinking, especially with regard to writing, research and using the Endnote software. Students confirmed that formative feedback is essential to improving their learning; students' state,

\section{"Our lecturer is giving individual treatment to her students and pointing out their strengths and weakness; I think the only way to improve our work is by pointing out their weakness so that they will try to avoid repeating the same mistakes". \\ "The feedback for this unit is running every week which is useful for improving the user satisfaction".}

By the same token, the literature review (Peat and Franklin 2002; Winstone and Millward 2012) indicates that formative feedback provides guidance for students to enhance their performance and increase their motivation towards the learning process.

Students developed two essential skills for writing reflective journals. The first related to the university professional skills, in respect to communication, information literacy, information technology literacy, and, most importantly, critical thinking and using the Endnote software to organize their references. The second was the ability to evaluate how a reflective journal could be beneficial especially in reviewing and recording the main key points of and students' responses to journal articles, textbooks and online resources. In support of the value of this exercise, students made the following statements in relation to the IS6 unit, in formal and informal feedback:

"The journals helped me in enhancing my skills related to analysing and evaluating; I improved my reading and writing skills a lot and learned how to write articles professionally. The journals were a good incentive to read, because, ultimately, it is the reading and critical thinking involved in the journals that I found to be the most effective learning tool. Finally, the journals we wrote weekly have helped me to understand the contexts of the unit better".

"Reading articles, writing journals and group works help me to improve my language skills. Thank you”.

"New area of study Assessments help to improve the assignment writing skills and achieve the learning outcomes".

"Different activities and non-boring stuff are being offered which is improving motivation". 
Based on students' feedback, it was noted that this tool becomes essential in the IS6 unit; in 2009 and 2010 , students appreciated this tool, as it assists them in developing and enhancing their communication skills not only for study but also for their future life.

The discussion board assessment was challenging to students, since the aim behind it is to share the latest knowledge with their colleagues and the lecturer. All students participated in this exercise, but sometimes their discussion was not well presented or well organized. Twice a week the lecturer provides feedback for each posted thread on the discussion board aligned to encourage her students to post more threads regarding the innovative information concerning the unit. Majority of the students indicated that this tool allow them to improve their research, writing, as well the debate skills, which are required for their studies as well workplace in future.

\title{
"Discussion board was helpful for learning process and also provide really good information".
}

"The best technique to encourage students to learn more, because different ideas are shared".

"It is free to express opinions, critical and interactive with the colleagues".

However, further changes to this assessment will be introduced in 2013 to improve the interaction and collaboration, by developing more debates on the blackboard and assigning a role in the discussion, especially the debate section, to each member in the class, especially the shy students.

The mini-tests were challenging to the students since as the first mini-test was aim to enhance middle and high level thinking of students. Majority of the student found this test practical and applied to real world especially the case study as they were required to identify the website's problems and adjust it according to the principles and guidelines of HCI. However, the mini-test two was more challenging to students since it aims to target students' high-level thinking. Completing the mini-tests by students was outstanding, as students indicated that this type of assessment was new to them since it challenge them to prompte several skills from reading, writing, critical thinking, and research. Finally, IS6 students confirmed that mini-tests were challenging and stimulating since several communication skills were promoted and improved by completing these assessments i.e. research, writing, technology, information, critical thinking and reading skills

\begin{abstract}
"An innovative way to test our knowledge (instead of memory) and skills behind the unit objectives, and using the new technology (i.e. using the computer to complete our test instead the traditional way)".
\end{abstract}

"Completing these [mini] tests improved my communication skills in general”.

The AP unit had various assessments that assisted students develop some or maybe all of the communication skills. The individual activity involved the study of materials, journal papers and other elements. These developed their reading, critical thinking and information skills. The discussions and the student participation in the forum fostered students' debating skills.

Regarding the group activities, the materials made available on the Moodle forum by the lecturer to be read and analysed by students to develop their reading, critical thinking and information skills. Tasks assigned by the lecturer to specific groups involved the development of technological, debating and thinking skills. The preparation of a report as a group and its on-line presentation in a forum involved the enhancement of writing, critical thinking and debating skills. The final individual work assigned to each student, to develop a prototype of an e-Commerce initiative and a business plan for it, involved the development of skills in research, reading, technology, information, critical thinking and written presentation. In order to produce the prototype students were required to use several skills as mentioned before. This individual final work was a major challenge for student participation and initiative. Students provided important feedback towards the unit and assessments:

"The unit made me communicates with my colleagues and I had to learn how to write and debate in an on-line environment". 


\begin{abstract}
"The final work requesting a business plan and a e-business initiative planning made me research actively, both for information on novel technologies, and also how to elaborate business plans and develop web sites".
\end{abstract}

"The myriad of materials provided requested me to be selective and able to assess what was important for each assignment and also for the whole unit".

MTeB also addressed several communication skills, as discussed below. The group activities consisting of reading a case study, which involved reading and information skills; preparing an analysis as a team, which fostered the reading, debating and critical thinking skills; and presenting the case study in class, which promoted the oral skills. Overall, despite the changes in the assessment structure (i.e. changing from two case studies to one case study), the scores were outstanding. It must be stated that the teacher has been quite demanding with both groups of students. Students were pleased with the case study approach:

"Case studies are mostly interesting and I like this methodology a lot since it increases my thinking and I can discuss with colleagues the best approaches and a consensus must be achieved".

As for the report, students were required to select a topic and then develop a report based on the literature review; this exercise targeted reading and information skills. The exercise outcome was a report using research techniques, and developed reading, research, critical thinking and written/oral presentation skills. The final exam was the last component of student assessments. This assessment promoted individual skills in critical thinking, reading, writing presentation, technology and information. Students provided the following feedback:

\footnotetext{
"The individual report was a lonely exercise but I could master myself in relation to a novel topic: I had to research about it, and select the parts that were more relevant to what was being requested. It was sometimes difficult but the teacher helped and was always available when I contacted him. It was a bit difficult but I was pleased with final result".
}

Finally, integrating these assessments in IS6, AP and MTeB was an extraordinary and challenging exercise for both the researchers and the students. The researchers provided the necessary guidelines and instructions to assist their students to complete these assessments on the basis of the unit objectives, and provided the appropriate feedback to their students to know whether they were on the right track. On the other hand, students were keen to complete these assessments, in order to learn and obtain the necessary skills that are required for their university studies and the lifelong learning process.

\title{
11. DISCUSSION - THEORETICAL AND PRACTICAL SIGNIFICANCE
}

Various assessments were used in the IS6, AP and MTeB units to improve communication skills and to increase self-confidence and self-esteem among postgraduate information systems students, since these skills are required not only at university but also in business.

Several studies (Diggins 2004; Lanning et al. 2011; Kuzma 2011; Moody 2002; Pavolvich et al. 2009) indicate that assessments play a major role in promoting communication skills among postgraduate information systems students; therefore, the lecturers should provide clear objectives and aims, presentation standards, guidelines for writing, marking guide, guidance on referencing style, and information about plagiarism, in relation to the assessments. Thanks to the clear instructions and guidelines, students managed to complete the assessments on time, and, most importantly, their communication skills were promoted and improved, since each assessment targeted specific communication skills that are required for the information systems students.

Furthermore, the class activities were designed to encourage and endorse communication skills among the postgraduate students, as this type of exercise will encourage more interaction and communication between students, and student-to-student feedback may also help students talk to one another about their adequacies and inadequacies in these units (Lanning et al. 2011, p.146). Furthermore, to keep this exercise running smoothly, the lecturers should provide frequent feedback to her/his students, as this feedback will encourage and increase 
students' motivation to continue working with these exercises to obtain information on innovations and to expand their communication skills.

Students were generous enough to share with us the following comments regarding the IS6 unit:

"It helps students to do more research; criticize; and discuss with other students in the class. Furthermore, a good mix of practice and theory motivates students to go to class each week; there is a good use of group and team dynamics skills; the feedback from this unit is running every week, which is useful for improving user satisfaction; the journals are very dynamic as they force us to be resourceful, using textbooks, websites, and articles'. The lecturer gives feedback to improve the writing, reading and referencing skills; I have learnt to write reflective reviews of the articles I read and therefore increased my learning".

"Our lecturer provided the class with a variety of activities such as designing an interface, reading articles, writing a journal; ... All these activities improved our skills such as reading, writing in a professional manner, design, etc. '..

The adeptness of the lecturer's approach to blending teaching and the students' experience of their learning in these units were demonstrated by consistently high scores in her feedback. Students have predominantly rated her as 'more than acceptable' or 'outstanding' in their responses and this has encouraged her to provide the cutting-edge information and develop challenging and exciting exercises to increase and improve their communication skills.

The outstanding students feedback indicate their satisfaction with the teachers and with the clarity of the teaching, availability to communicate with students, capacity to stimulate interest, level of organization of the teaching, and feedback provided, and overall appreciation of the teachers.

This study developed new theoretical and practical contribution in promoting communication skills among information systems students as various assessments were integrated in the three postgraduate units. This study examined how three postgraduate units from Portugal and Australia managed to enrich and expand the students' communication skills via assessments, activities, debates, online discussion, report-writing and reflective journals, and to develop their deep and critical thinking, and this was achieved by implementing the action research in this study.

It was a challenging exercise not only for the students but also for the lecturers, who were required to ensure that these assessments and activities were able to improve the students' skills, achieve the objectives and aims of the unit, Master's degrees, universities, and meet the needs of businesses. The study aims was confirmed by students' feedback formal and informal that completing these units allowed them to heighten their communication skills, as the majority of students indicated that these assessments and activities were very challenging, exciting as well as new skills were obtained, and their knowledge and experience were enriched.

The lecturers' regular feedback and discussion sections confirmed that this study managed to promote the students' communication skills and to develop new ways of learning that fostered individual learning experience. Furthermore, the lecturer's feedback encourages students to identify their weaknesses in the learning process, and this feedback is essential for enabling students to improve their submissions in the future. Furthermore, the researchers' final feedback informs students about their level of performance on reaching an end point, such as the end of a topic, or specific assessment task, or at the conclusion of the unit.

Integrating communication skills in the information systems assessments has a positive influence on the students; they expressed their satisfaction by stating: 'Reading articles, writing journals and group work help me to improve my language skills. The presentation is a good way to improve speaking ability, especially speaking in front of the public; analysing a case study improved my critical thinking skills; the on-line unit is very well planned and provides excellent feedback which helps us to improve our knowledge and skills. Furthermore, students confirm that

"Our lecturers were very keen to present the latest learning methods and techniques to their students'; the majority indicate that 'their lecturers were very helpful, very interactive, knowledgeable, goal-oriented, creative, committed, unique, industrious and fun to work with”. 
This experience was extremely important and essential from the researchers' perspective, as it equips the information systems students with the ability to research, read, analyse, write, present, critical thinking, solve problems, and decision-making technology, debate and written presentation/oral skills. Researchers have found that teaching communication skills to the postgraduate information systems can be via various methods i.e. teamwork, discussion board, presentation, debates, reflective journals, and report writing. The researchers have observed that students require some guidance and supervision to promote and achieve their communication skills. In addition, to ensure the smooth and success of this experience, researchers recommend other researchers to develop and design assessments to match the unit, degree, university and business' objectives and aims. Furthermore, these assessments should be reviewed yearly in line to match the market needs, and make them challenging, exciting and fun for the students. The most essential aspect of this experience is researchers' regular feedback to the students and their commitment to this experience.

The results from this study added a new theoretical and practical contribution to higher-education teaching and learning literature, especially the action research for teachers to promote and develop communication skills among information systems units. By introducing the CSM model and assessments in this study researcher and academics from Information Systems as well as other disciplines can adopt this approach in their teaching or for further study in the future to promote student's communication skills, self-confidence, self-esteem, and expands their professional networks. In conclusion, to promote student's communication skills, continuous formative feedback should be accessible between the stages in the CSM Model to ensure if students acquire the necessary communication skills by completing the assessments. This feedback will encourage and increase the students' motivation to continue working with these exercises in order to obtain information on innovations and expand their communication skills.

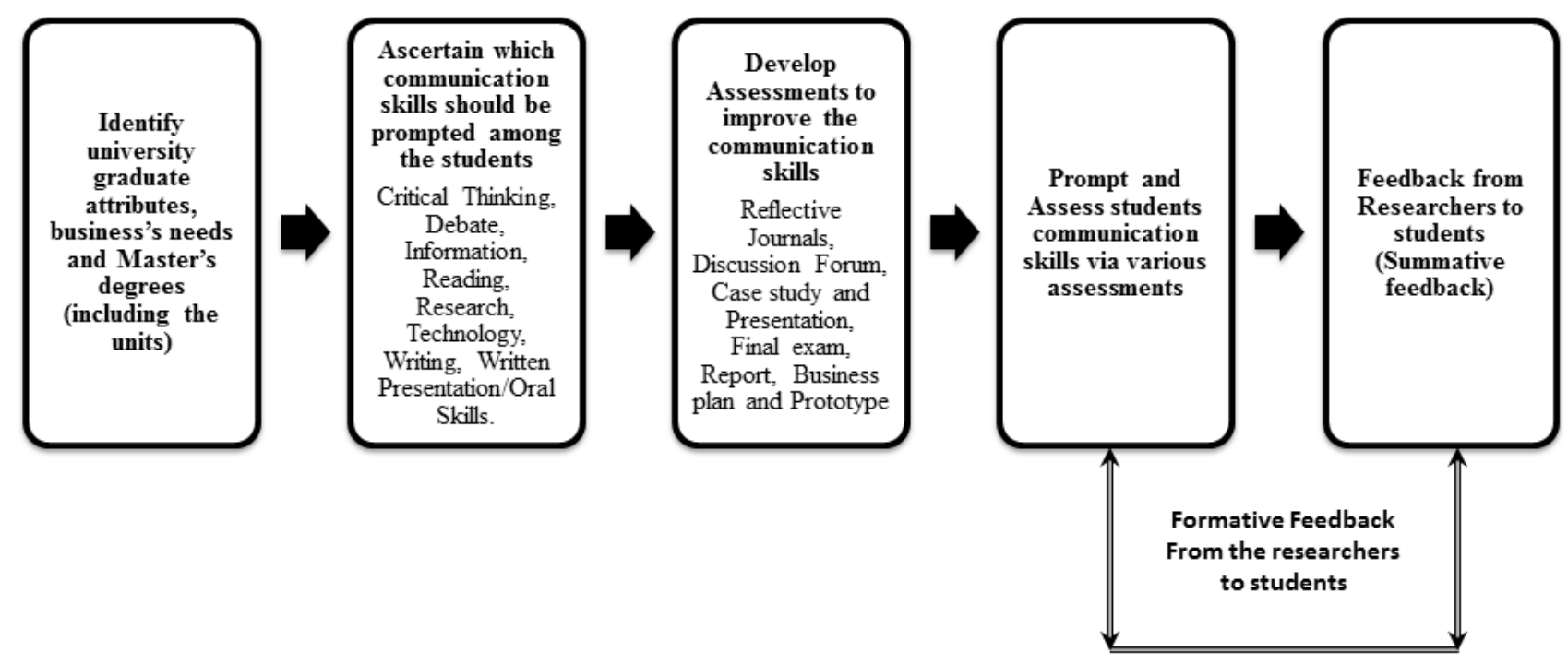

Fig 3: Communication skills model_2 (CSM2) Prepared by the researchers

Figure 3 illustrated the new addition to CSM2 model as formative feedback is essential to promoting students' communication skills to improve, accelerate and enhance learning and to identify the problems within the assessments in the early stages (Koh 2008; Wingate 2010).

\section{CONCLUSION}

This study presents how the teaching of Information Systems units at the postgraduate level in Australia and Portugal develops students' communication skills via the assessments. The COM model assisted the researchers to promote the necessary communication skills among IS students. Research results indicate that the integration of communication skills in assessments allows students to enhance these skills; furthermore, different 
assessments can develop different skills, and several assessments contribute to the enhancement and development of the same skills.

The outcomes from this study entrenched the study research question and the literature review and confirm that the integration of these communication skills meets the expectations of students, academics and businesses.

Completing these assessments in information systems units promote other skills in relation to students' selfconfidence and self-esteem, and expand their professional networks. Moreover, to keep this exercise running smoothly between the postgraduate units, the lecturer should provide regular feedback to her/his students, since this feedback will encourage and increase the students' motivation to continue working with these exercises in order to obtain information on innovations and expand their communication skills. This type of feedback was added to CSM model to confirm if students are in the correct track, allow students to learn from their mistakes, and develop more confidence and motivation among students in line to learn some new knowledge and skills behind completing these assessments.

The CSM model is a good candidate model to be implemented and tested with other units and in other countries in order to promote students' communication skills using the various strategies. Further research will be carried out in the future to develop a set of guidelines for the higher education sector to promote these communication skills, as they have become essential not only for study purposes but also in the business sector. Finally, the researchers will continue to present regular feedback to their students, but new approaches will be used, e.g. audio feedback (MP4) instead of face-to-face feedback, and the new study outcomes will be published next year.

\section{REFERENCES}

Albitz, R. (2007). The What and Who of Information Literacy and Critical Thinking in Higher Education Libraries and the Academy, 7(1), 97 - 109

Avison, D., Lau, F., Myers, M., \& Nielsen, P. A. (1999). Action Research - To make academic research relevant, researchers should try out their theories with practitioners in real situations and real organizations. Communications of the ACM, 42(1), 94-97.

Biesta, G., \& Stams, G. (2001). Critical Thinking and the Question of Critique: Some Lessons from Deconstruction Studies in Philosophy and Education, 2057 - 74.

Chi, M., VanLehn, K., Litman, D., \& Jordan, P. (2011). Empirically evaluating the application of reinforcement learning to the induction of effective and adaptive pedagogical strategies. User Model User-Adap Inter, $21,137-180$

Clarke, M. (2003). Reflection: Journals and Reflective Questions a Strategy for Professional Learning Paper presented at the NZARE/AARE Conference Auckland, New Zealand

Creswell, J. W. (2003). Research Design Qualitative, Quantitative, and Mixed Methods Approaches (Second ed.). USA: SAGE Publications.

Curtin University (2010). Teaching and Learning in Curtin Perth - WA.

Curtin University (n.d.). Graduate Attributes and Professional Skills Program http://www.business.curtin.edu.au/business/current-students/unit-and-course-information/graduateattributes-and-professional-skills-program. Accessed 14 May 20122012.

Dewey, J. (1933). How We Think. A restatement of the relation of reflective thinking to the educative process. Boston: D. C. Heath.

Diggins, M. (2004). Teaching and Learning Communication Skills in Social Work Education Social Care Institute for Excellence.

Drury, H., \& Taylor, C. Providing the discipline context for skills development: report on the production of an interactive video for oral and visual communication in the biological sciences In HERDSA Annual International Conference Melbourne 1999 (pp. 1-9)

Elliot, J. (1991). Action Research for Educational Change. Buckingham: Open University Press.

Gilbert, T. (2006). Mixed Methods and Mixed Methodologies - The Practical, the Technical and the political Journal of Research in Nursing, 11(3), 205 - 217.

Halpern, D. (1998). Teaching Critical Thinking for Transfer Across Domains American Psychologist, $53(4), 449$ $-455$.

Harrison, R., \& Reilly, T. (2011). Mixed Methods designs in Marketing Research Qualitative Market Research: An International Journal, 14(1), 7 - 26. 
Hattangdi, A., \& Ghosh, A. Enhancing the quality and accessibility of higher education through the use of Information and Communication Technologies. In International Conference on Emergent Missions, Resources, and the Geographic Locus in Strategy as a part of the 11th Annual Convention of the Strategic Management Forum (SMF), India 2008 (Vol. 2011, pp. 1- 14, Vol. 28 March )

Hesse-Biber, S. (2010). Emerging Methodologies and Methods Practices in the Field of Mixed Methods Research. Qualitative Inquiry, 16(6), 415 - 418.

Hubbs, D., \& Brand, C. (2010). Learning from the Inside Out: A Method for Analyzing Reflective Journals in the College Classroom Journal of Experiential Education, 33(1), 56- 71.

Hubner, S., Nuckles, M., \& Renkl, A. (2010). Writing learning journals: Instructional support to overcome learning-strategy deficits Learning and Instruction, 20, 18 -29.

Karkukly, W. (2011). An Investigation into Outsourcing of PMO Functions for Improved Organizational Performance: A Quantitative and Qualitative Study Trafford Publishing

Koh, L. C. (2008). Refocusing formative feedback to enhance learning in pre-registration nurse education. Nurse Education in Practice, 8(4), 223-230, doi:10.1016/j.nepr.2007.08.002.

Kuzma, J. (2011). Using Online Technology to Enhance Student Presentation Skills. Worcester Journal of Learning and Teaching, 5.

Lanning, S. K., Brickhouse, T. H., Gunsolley, J. C., Ranson, S. L., \& Willett, R. M. (2011). Communication Skills Instruction: An Analysis of self, peer-group, student instructors and faculty assessment Patient Education and Counseling, 83(145 - 151).

Li, V. (2010 ). eSelf-assessment:A case study in English language learning (Hong Kong) for enhancing Writing and Oral Presentation Skills. Paper presented at the International Conference on Education Technology and Computer (ICETC) Shanghai

Maudsley, G. (2011). Mixing it but not mixed-up: Mixed methods research in medical education (a critical narrative review) Medical Teacher, 33(2), 92 - 104.

McGrath, H., \& O'Toole, T. (2012). Critical Issues in Research Design in Action Research in an SME Development Content. European Journal of Training and Development, 36(5), 508 - 526.

McNiff, J., \& Whitehead, J. (2005). All You Need to Know About Action Research London: SAGE.

Mertler, C. (2006). Action Research: Teachers and Researchers in the classroom Sage Publications, Inc.

Mills, G. E. (2000). Action Research: A Guide for the Teacher Researcher: Upper Saddle River, NJ: Prentice Hall Inc.

Mills, G. E. (2007). Action Research : A guide for the Teacher Researcher: Pearson Merrill Prentice Hall.

Moody, J. Teaching Effective Listening Skills to Information Systems Majors In Information Science - InSITE "Where Parallels Intersect", 2002 (pp. 1113 - 1116)

Pavolvich, K., Collins, E., \& Jones, G. (2009). Developing Students' Skills in Reflective Practice: Design and Assessment. Journal of Management Education, 23(1), 37 - 58.

Peat, M., \& Franklin, S. (2002). Supporting student learning: the use of computer-based formative assessment modules Bristish Journal of Educational Technology, 33(5), 515 - 523.

Reason, P., \& Bradbury, H. (2001). Handbook of Action Research: Participative Inquiry and Practice London Sage.

Sagor, R. (2011). The Action Research Guidebook: Corwin Press Inc.

Scott, I. (2011). The Learning Outcome in Higher Education: Time to think again? Worcester Journal of Learning and Teaching, 5, $1-8$

Sullivan, O. (2011). An End to Gender Display Through the Performance of Housework? A Review and Reassessment of the Quantitative Literature Using Insights From the Qualitative Literature. Journal of Family Theory \& Review, 1- 13.

Tanian, S., \& Ryan, M. An Approach to teaching professional communication skills to marketing students: a discussion and review. In ANZMAC, NewZleand, 1998 (pp. 2591 - 2602)

Teddlie, C., \& Tashakkori, A. (2009). Foundations of Mixed Methods Research - Integrating Quantitative and Qualitative Approaches in the Social and Behavioral Sciences. USA: SAGE Publisher

Tucker, M., McCarthy, A., Hoxmeier, J., \& Lenk, M. (1998). Community Service Learning Increases Communication Skills Across teh Business Curriculum. Business Communication Quarterly, 61(2), 89 -99 .

Van Deursen, A. J. A. M., Van Dijk, J. A. G. M., \& Peters, O. (2011). Rethinking Internet skills: The contribution of gender, age, education, Internet experience, and hours online to medium- and contentrelated Internet skills. Poetics, 39(2), 125 - 144.

Wallace, T., Stariha, W., \& Walberg, H. (2004). Teaching, Speaking, Listening and Writing International Academy of Education

Westerman, M. (2011). Conversation analysis and interpretive quantitative research on psychotherapy process and problematic interpersonal behavior. Theory \& Psychology, 21(2), 155 -178. 
Westerman, M., \& Yanchar, S. (2011). Changing the terms of the debate: Quantitative methods in explicitly interpretive research. Theory \& Psychology, 21(2), $139-154$.

Wingate, U. (2010). The impact of formative feedback on the development of academic writing Assessment \& Evaluation in Higher Education, 35(5), 519 - 533.

Winstone, N., \& Millward, L. (2012). Reframing perceptions of the lecture from challenges to opportunities Paper presented at the The Higher Education Academy - STEM, London - England

Woei, L., \& White, G. The Promotion of Critical Thinking Through The Use Of an Online Discussion Board: Asking the Right Questions? In Global Learn Asia Pacific 2010 (pp. 4277 - 4283)

Wolcott, S., Baril, C., Cunningham, B., Fordham, D., \& Pierre, K. (2002 ). Critical thought on critical thinking research J. of Acc. Ed, 2085 - 103.

Worley, P. (2008 ). Writing Skills Essential in Tech Ed Today Tech Directions, 68(2), 17 - 19

Yang, Y., Newby, T., \& Bill, R. (2008). Facilitating interactions through structured web-based bulletin boards: A quasi-experimental study on promoting learners' critical thinking skills Computers and Education, 50 $1572-1585$ 